\title{
The long-term trends in changing educational organisation in the Ukraine
}

\author{
Svetlana Kudrjavtseva \\ International Research and Training Centre (UNESCO) for Information Technologies and \\ Systems, Kiev, Ukraine
}

\begin{abstract}
The paper describes the long-term trends in changing educational organisation in the Ukraine, namely, ICT infrastructure development, ICT educational staff development and teachers' education, management and organisation of distance learning infrastructure, curriculum and pedagogy development, educational information content and the elaboration of services.
\end{abstract}

Keywords: life-long learning, changing educational organisation, information and communication technologies, distance education, curriculum and pedagogy

\section{INTRODUCTION}

We can conclude that information and communication technologies (ICT) in various forms have come to play an important role in Ukrainian life at present and will continue to do so in the foreseeable future. The questions regarding changing educational organisation are not only about technical conditions but also ensuring that the Ukraine will be mentally prepared.

Teaching and learning have a very central role in preparing people mentally for the development of the information society, where one of the features is life-long learning. Designing the changing educational organisation to support life-long learning via distance learning technologies must take account of the need for everyone working or studying at an educational establishment to have access to ICT, technical and pedagogical support, information content and services. 


\section{MAIN TRENDS IN CHANGING EDUCATIONAL ORGANISATION IN THE UKRAINE}

Some organisations will be created in the Ukraine from scratch, in order to meet the education and training needs of a networked, multimedia society. However, the repository of subject expertise and skills of teaching will, at least initially, be located in traditional institutions such as schools, colleges and universities, training departments in academic establishments or commercial companies, or in existing open and distance learning institutions. So, main trends for changing educational organisation in the Ukraine will be: ICT - infrastructure development; ICT - educational staff development and teachers' education; management and organisation of distance learning infrastructure; curriculum and pedagogy development; educational information content and services development.

ICT - infrastructure development: Educational organisations in the Ukraine have realised that for sustainable economic growth it is necessary to change the approach to their functioning, mainly arising from development of effective ICT infrastructure. Lack of the pedagogical architecture of a technical solution is one of the main obstacles to support for effective telematics-based distance education in changing an educational organisation. The key to success in changing educational organisation is not in the speed of computer and internet channels, it is the liberation of educators, whose understanding and creative use of technology can help to achieve higher levels of excellence for themselves and their students. Critical to the successful use of telematics in education will be the creation of new organisational structures. The solution of the given problem has been found in the creation of the International Centre of Distance Learning Technologies within an academic establishment. The Centre focuses on perceptions of the best practice existing on aspects of 'world information space', and transmission of the best practice from the Ukraine to the rest of the world.

ICT - educational staff development and teachers' education: Having five years experience in teachers' training we can observe the teachers' needs identified in the study, and divide these into three major areas: access to ICT, appropriate training, and ongoing support to encourage progression. Teachers need to know where ICT development fits into organisation priorities and development plans; that the time spent in developing their skills and knowledge is valued; and that they are not working in isolation. Below we look at a range of five main streams for teachers' professional development activities in the ICT area.

Stream 1: skills in using particular software applications. Short courses were developed in using specific applications of ICT. 
Stream 2: integration of ICT into existing curricula with which a teacher is working. Courses were developed in "ICT used for organisation discussion" and "Electronic learning material preparation".

Stream 3: ICT related changes in curricula. An introductory course "Curriculum and Information Technology" has provided the opportunity to change the nature of experimental work in educational organisation.

Stream 4: changes in teacher and student roles in learning. In this case teachers need a course on "Distance learning management".

Stream 5: instructional design of telematics-based distance learning and teaching. A telematics-based distance curriculum for teachers' training on "The use of ICT in teaching activity" has been developed and disseminated.

Management and organisation of distance learning infrastructure: Experience has shown that ICT development of the educational organisation is ineffective unless it is accompanied by appropriate management strategies, which are sensitive to changes. Management of a networked educational organisation needs to dispose of barriers to the implementation of ICT by

- developing network services;

- providing all students and staff with full individual access to ICT;

- creating within each institution an open and distance learning policy;

- establishing a training plan for staff development;

- providing curriculum and pedagogy development;

- implementing resource centres for support of electronic resources;

- providing the implementation of telematics-based distance courses;

- keeping within educational technology standards.

Curriculum and pedagogy development: The basis and background of the pedagogy development within a networked educational organisation is provided by epistemologies of social constructivism and the philosophy of dialogic teaching as they were defined by Alexei Dovgialla (Bykov, Dovgiallo and Kommerce, 2001). The learning system has as a consequence been changed as the object of support from a focus on active learning to one on cognitive learning, and to constructive learning. In the Ukraine there were and still are two main directions within the problem-solving approach for education: modelling problem-solving as a process in learning and teaching, and problem-based teaching and learning.

The elements of problem-solving modelling of learning and teaching were initiated in the Ukraine by a team under the supervision of Professor Dovgiallo at the end of the 1960s. During the subsequent years the team's investigations were concentrated on working out the fundamentals of generalised problem-solving theory and its application to the educational process. The effectiveness of applications of problem-based teaching is dependent on a methodically correct organisation of a process in which the main factor is the teacher's control of the activity for every learner through 
the organisation of collaborative activities of learners when they work in problem-solving situations. Problem-oriented methods usually require more time and highly developed creative skills and abilities, so it is not disseminated widely throughout the Ukrainian educational system.

Educational information content and services development: The past few years have seen considerable advances in educational information services. Creating effective educational information content and services across a networked educational organisation will facilitate development of the quality of learning material, new teaching methods, producing and distributing learning material more economically, enriching instruction by using modern media, and improving e-teaching.

\section{CONCLUSION}

It is possible to identify a six-point strategy for the future use of telematics in changing educational organisation: to identify key target groups and markets for on-line, multimedia education and training; to develop a clear vision for the use of ICT in education; to find ways to fund the development of large quantities of multimedia learning materials; to keep the human role in teaching by linking 'real' people with students through telecommunications; to create new (or transform existing) curricular models; to develop new institutional or oganisational structures; and to provide political leadership in the development of system-wide education and training networks.

\section{REFERENCES}

Bykov, V., Dovgiallo, A., and Kommerce, P.A.M. (2001) Theoretical backgrounds of educational and training technology. International Journal of Continuing Engineering Education and Life-long Learning, 11, (4-6), 412-441

\section{BIOGRAPHY}

Svetlana Kudrjavtseva is the head of department of the International Research and Training Centre (UNESCO) for Information Technologies and Systems. She has been involved in a number of European Projects. Her current research is focused on the application of e-technologies to teacher training. 